\title{
The Potential of Cytotoxin and Antiviral in Sargassum polycystum and Sargassum ilicifolium's Polysaccharides Extract
}

\author{
Dwi Lestari Widya Ningsih1,2*, Agus Trianto ${ }^{1}$, Ita Widowati ${ }^{1}$, Rexie Magdugo ${ }^{2,3}$, \\ Anicia Hurtado ${ }^{3}$, Christel Marty², Nathalie Bourgougnon ${ }^{2}$ \\ ${ }^{1}$ Marine Science Study Program, Diponegoro University \\ Jl. Prof. H. Soedarto, S.H., Tembalang, Semarang, Jawa Tengah, 50275 Indonesia \\ 2Université Bretagne Sud, EA 3884, LBCM, IUEM, F-56000 Vannes, France \\ 3Integrated Services for the Development of Aquaculture and Fisheries (ISDA) Inc., MacArthur Highway, Tabuc \\ Suba, Jaro, 5000 Iloilo City, Philippines. \\ Email : dlwidyan@students.undip.ac.id
}

\begin{abstract}
Marine algae known as one producers of bioactive compounds. This study aims to analyze the cytotoxicity and antiviral activity in Sargassum polycystum and Sargassum ilicifolium tested with Herpes Simplex Virus (HSV). The polysaccharides extract of algae was used in this study, as sulfated polysaccharides have been reported has bioactivity. Cytotoxicity either antiviral could be correlated with the sulfate content as well as nature and chemical composition of the polysaccharides. Cytotoxicity and antiviral analysis based upon cell viability. Using the Vero cell / HSV-1 model, cytotoxicity was evaluated by incubating cellular suspensions $\left(3.5 \times 10^{5}\right.$ cells. $\left.\mathrm{mL}^{-1}\right)$ with various dilutions (concentration from 1 to $500 \mu \mathrm{g} \cdot \mathrm{mL}^{-1}$, four wells per concentration) of fractions in 96-well plates (72h, $37^{\circ} \mathrm{C}, 5 \% \mathrm{CO}_{2}$ ) in Eagle's MEM containing 8\% FCS. The cells were examined daily under a phase-contrast microscope to determine the minimum concentration of hydrolysate dry matter that induced alterations in cell morphology, including swelling, shrinkage, granularity and detachment. Algae S. illicifolium was found to have the highest cytotoxic content in each solution compared to S. polycystum. Algae S. illicifolium in $\mathrm{KOH} \mathrm{4M} \mathrm{(cellulose)}$ reached 2,707 $\mu \mathrm{g} \cdot \mathrm{ml}^{-1}$, then $\mathrm{HCl} \mathrm{pH} 2$ (fucoidan) was 2,477 $\mu \mathrm{g} \cdot \mathrm{ml}^{-1}$, then $\mathrm{CaCl}_{2} 2 \%$ (fucoidan) was 2,362 $\mu \mathrm{g} \cdot \mathrm{ml}^{-1}$, and in $\mathrm{Na}_{2} \mathrm{CO}_{3} 3 \%$ (alginates) was 2,134 $\mu \mathrm{g} \cdot \mathrm{ml}^{-1}$. For antiviral, S. polycystum contained the highest antiviral compounds compared to S. illicifolium with $\mathrm{KOH} 4 \mathrm{M}$ (cellulose) solution was reached $67.02 \mu \mathrm{g} . \mathrm{ml}^{-1}$. Then in $\mathrm{Na}_{2} \mathrm{CO}_{3}$ $3 \%$ (alginates) which was $33.25 \mu \mathrm{g} . \mathrm{ml}^{-1}$, then $\mathrm{CaCl}_{2} 2 \%$ (fucoidan) which was $31.62 \mu \mathrm{g} . \mathrm{ml}^{-1}$, and $\mathrm{HCl} \mathrm{pH} 2$ (fucoidan) was $30.08 \mu \mathrm{g} . \mathrm{ml}^{-1}$. After all, the highest bioactivity compounds was found with $\mathrm{KOH} 4 \mathrm{M}$ (cellulose) for cytotoxicity in S. ilicifolium and antiviral activity in S. polycystum.
\end{abstract}

Keywords: bioactivity, seaweed, Sargassum sp, Herpes Simplex Virus (HSV).

\section{Introduction}

Herpes Simplex Virus (HSV), commonly known as herpes, is a member of a family of viruses having genomes consist of a single large double-stranded DNA that most widespread pathogens among the humans (Laine et al. 2014). There are two type of HSV called HSV type-1 and HSV type-2 (Gebreyohannes, 2014). HSV-1 reported infects 70\% - $80 \%$ in population of low socioeconomic status and $40 \%$ to $60 \%$ in populations of improved socioeconomic status (Mustafa et al., 2016). This virus highly common in patients with hematologic disease (Rodriguez-Medina et al., 2017). HSV-1 primarily infects mouth, throat, face, eye, and central nerves system, while HSV-2 caused anogenital infections (Chayavichitsilp et al., 2009). HSV infections contract through directly contact with a lesion or body fluid of infected person. HSV also termed a "broad cell tropic" due to the infectivity ranges is from the host epithelial cells, fibroblasts, and lymphocytes to the neuronal cells (Vadlapudi et al., 2013).

There are several drugs that have been known in the general society that could defeats HSV, such as Acyclovir, Brivudine, Valacyclovir, Famciclovir and Foscavir those may shorten healing time, reduce lesion size and associated pain to the patient (Razonable, 2011). Development of the HVS drugs from marine resources have conducted by researchers from many countries. Seaweed produce a variety of compounds with pharmacological activities, including antiviral, anti inflammatory and others, and are potential sources of new therapeutic agents (Peréz, et al., 2016) Previous research reported the potent of anti-viral polysaccharides, obtained from Gelidium cartilagineum (Linnaeus) 
Gaillon. The substances was active against the influenza $B$ virus and mumps. Polysaccharides from various algae have been studied for structural and biological effects. Sulfated polysaccharides have been shown to have a variety of bioactivities, such as immune-modulatory, anti-tumor, anticoagulant, antioxidant properties, and anti-viral activities for against various viruses (Guo, et al. 2017).

Alga Sargassum is brown seaweed from Phaeophyceae which showed has richest antioxidant compared the red algae (Rhodophyceae) and green algae (Chlorophyceae) (Kelman et al., 2012). Sargassum is one of seaweed genera found varied spatially, seasonally and abundantly (Setyawidati et al. 2018). In this study, we evaluated the potential of polysaccharides in S. polycystum and S. ilicifolium extracts as a based material for cytotoxicity and antiviral for the HSV's patient.

\section{Material and Methods}

Brown algae S. ilicifolium was collected in Luzon, Currimao Beach, llocos Norte, while the S. polycystum was taken in Visayas, Lamanok Island, Anda, Bohol the Philippines.

\section{Extraction}

The extraction of polysaccharides was based on the method used in the Laboratoire de
Biotechnologie et Chimie Marines (LBCM), Université de Bretagne Sud (UBS), Vannes, France. Five grams of algae sample, finely grounded, then inserted into a Soxhlet cartridge, the sample was placed inside the extractor Soxhlet. Extraction was carried out with 150 $\mathrm{ml}$ acetone $100 \%$ for 1 hour. Then, the second extraction with a Soxhlet extractor was carried out with $150 \mathrm{ml}$ of absolute ethanol for 1 hour. The process was applied to remove pigments, lipids, and proteins in the alga.

These dried solid residues are immersed in $125 \mathrm{~mL}$ of distilled water and are extracted at $80^{\circ} \mathrm{C}$ for $2 \mathrm{~h}$ with stirring. After filtration with gauze, the filtrate containing the polysaccharides was collected and cooled. A volume of absolute ethanol was twice of the filtrate volume that was gradually poured into the filtrate. The polysaccharides precipitation was formed with the vigorous manual stirring. This precipitate is disaggregated and washed with ethanol. The fibers obtained are placed in an oven at $60^{\circ} \mathrm{C}$ for 1 day. They are then finely ground in a mortar and stored in an Eppendorf tube in the dark, in a dry place, and at room temperature $\left(18-22^{\circ} \mathrm{C}\right)$, until use. For the same sample, the extractions of the polysaccharides were carried out in duplicate. Polysaccharide powders are analyzed using an infrared spectrometer and then analyzed using The Unscrambler software. The protocols used for these physicochemical and statistical analysis techniques are detailed in the rest of this manuscript.

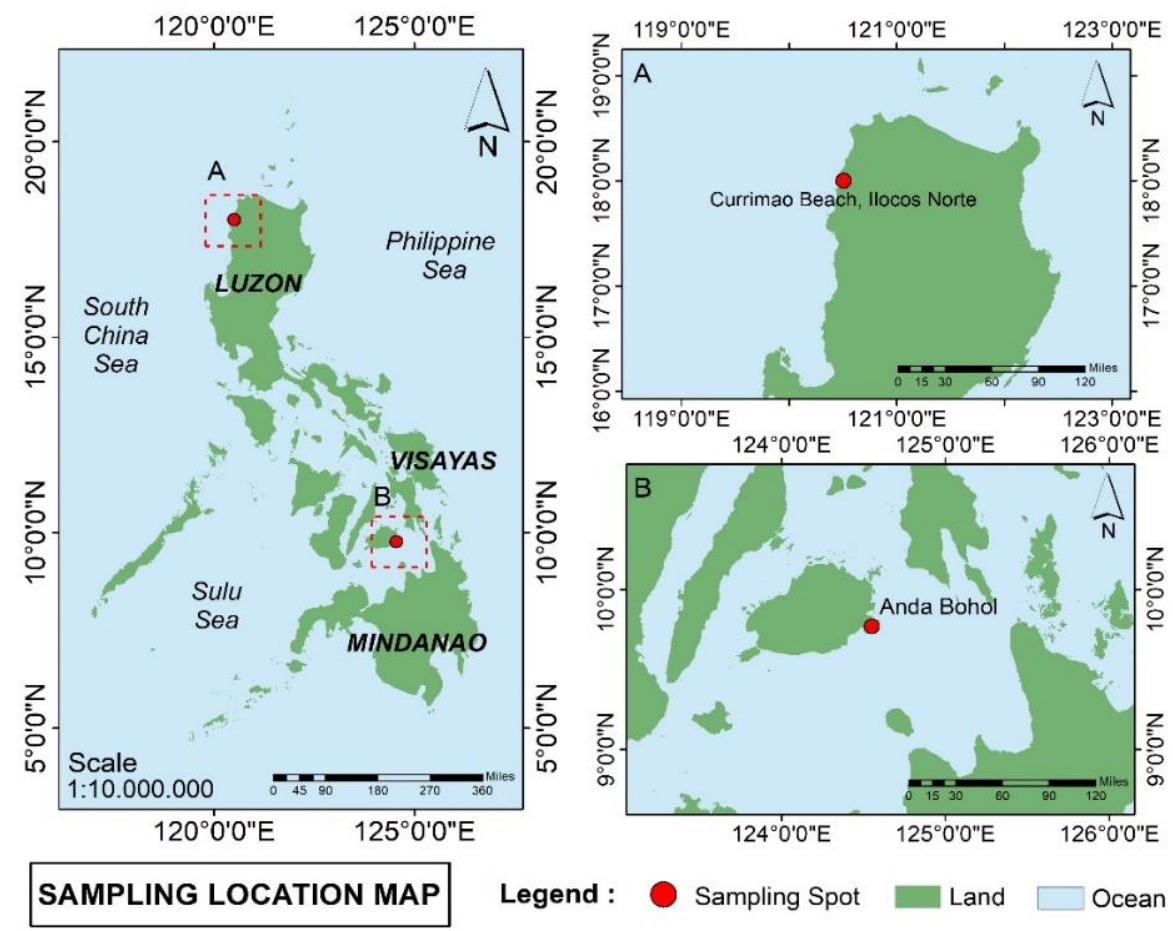

Figure 1. Sampling location map 
The next step was the extraction of polysaccharide used solvents $\mathrm{CaCl}_{2}(2 \%), \mathrm{HCl}(\mathrm{pH} 2)$, $\mathrm{KOH}(4 \mathrm{M})$, and $\mathrm{Na}_{2} \mathrm{CO}_{3}(3 \%)$, these different solvents for collecting difference targets. $\mathrm{CaCl}_{2}(2 \%)$ and $\mathrm{HCl}$ $(\mathrm{pH} 2)$ aimed to collect the sulfated polysaccharides in fucose (fucoidan), while $\mathrm{Na}_{2} \mathrm{CO}_{3}(3 \%)$ aimed to collect alginates, then $\mathrm{KOH}(4 \mathrm{M})$ aimed to collect cellulose/hemicellulose. Five grams of polysaccharide extract obtained in previous method was added to $100 \mathrm{~mL} \mathrm{CaCl} 2$ (2\%). Then it was heated at $70^{\circ} \mathrm{C}$ for two hours, then filtered. The liquid extract that has been obtained was stored and the solid extract remaining as residue I then was added 300 $\mathrm{mL} \mathrm{HCl}(\mathrm{pH} 2)$ then heated at $70^{\circ} \mathrm{C}$ for two hours then centrifuged, filtered and obtained the residue II. The next stage was the residue II was added $300 \mathrm{~mL}$ $\mathrm{Na}_{2} \mathrm{CO}_{3}(3 \%)$, heated at $80^{\circ} \mathrm{C}$ for one hour, then centrifuged to obtain the residue III. After that, the residue III was added with $300 \mathrm{~mL} \mathrm{KOH} \mathrm{(4M),} \mathrm{placed}$ at room temperature for one hour, then centrifuged and obtained the final solid extract as final residue and liquid extracts for each solvents. The liquid extracts that had been obtained in each solvents then through the dialysis stage. The liquid extracts used a 12-14 kDa membrane on dialysis for $5 d$ in $15 L$ of distilled water. Distilled water was renewed every $6 \mathrm{~h}$ in the first two days then every $12 \mathrm{~h}$ the following day. After the dialysis stage, all the liquid extracts were freeze dried used Alpha 1-2 LDplus Martin Christ then dry polysaccharide extracts was obtained.

\section{Cytotoxicity analysis}

The method from Hardouin et al. (2013) was selected for evaluating the cytotoxicity and antiviral in Sargassum of polysaccharide extracts. Cytotoxicity analysis based upon cell viability. Using the Vero cell / HSV-1 model, cytotoxicity was evaluated by incubating cellular suspensions $\left(3.5 \times 10^{5}\right.$ cells. $\left.\mathrm{mL}^{-1}\right)$ with various dilutions (concentration from 1 to 500 $\mu g . \mathrm{mL}^{-1}$, four wells per concentration) of fractions in 96-well plates $\left(72 \mathrm{~h}, 37^{\circ} \mathrm{C}, 5 \% \mathrm{CO}_{2}\right)$ in Eagle's MEM containing $8 \%$ FCS. The cells were examined daily under a phase-contrast microscope to determine the minimum concentration of hydrolysate dry matter that induced alterations in cell morphology, including swelling, shrinkage, granularity and detachment.

Cytotoxicity by cell viability was tested using the neutral red dye method. Optical density (OD) was measured at $540 \mathrm{~nm}$. The $50 \%$ cytotoxic concentration $\left(\mathrm{CC}_{50}\right)$ was defined as the concentration that reduced the OD of treated cells to $50 \%$ of that of untreated cells. CC50 values were expressed as the percentage of destruction (\%D): $\left[(O D c)_{c}-(O D c)_{\text {Mock }} /(O D c)_{c}\right] \times 100$, where $\left(O D_{c}\right)_{c}$ and $\left(\mathrm{OD}_{\mathrm{c}}\right)_{\text {моск }}$ are the $\mathrm{OD}$ values of the untreated cells and treated cells, respectively (Langlois et al. 1986).

\section{Antiviral analysis}

Antiviral assays based upon cell viability using the Vero cell/HSV-1 model, $100 \mu \mathrm{L}$ of cell suspension $\left(3.5 \times 10^{5}\right.$ cells. $\left.\mathrm{m}^{-1}\right)$ in Eagle's MEM containing $8 \%$ FCS was incubated with $50 \mu \mathrm{L}$ of a dilution of fractions (concentration from 10 to $500 \mu \mathrm{g} \cdot \mathrm{ml}^{-1}$ ) in 96-well plates $\left(72 \mathrm{~h}, 37^{\circ} \mathrm{C}, 5 \% \mathrm{CO}_{2}\right)$. Three replicates were infected using $50 \mu \mathrm{L}$ of medium and a virus suspension at a multiplicity of infection (MOI) of $0.001 \mathrm{ID} / 50 /$ cells. After incubation, antiviral activity was evaluated by the neutral red dye method. The antiherpetic compound acyclovir [9-(2hydroxyethoxymethyl) guanine] was used as reference inhibitor. The $50 \%$ effective antiviral concentration (EC) was expressed as the concentration that achieved $50 \%$ protection of virusinfected cells from virus-induced destruction. The OD was related directly to the percentage of viable cells, which was inversely related to the cytopathic effect (CPE). The linear regression was determined for each assay on the basis of cell controls (O\% CPE) and virus controls (100\% CPE). Data were expressed as a

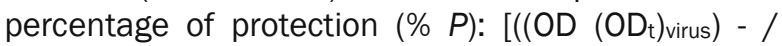
$\left.\left.\left(O D_{c}\right)_{\text {virus }}\right) /\left(\left(O D_{c}\right)_{\text {Mock }}-\left(O D_{c}\right)_{\text {virus }}\right)\right] \times 100$, where $\left(O D_{t}\right)_{\text {virus }}$ is the $O D$ of the test sample, $\left(O D_{c}\right)_{\text {virus }}$ is the $\mathrm{OD}$ of the virus control and $\left(O D_{\mathrm{c}}\right)_{\text {моск }}$ is the $\mathrm{OD}$ of the mock-infected control (McLaren et al. 1983; Langlois et al.,1986).

\section{Result and Discussion}

The bioactivity compounds of polysaccharides in algae shown in Table 1. Algae S. illicifolium was found to have the highest cytotoxic content in each solution compared to $S$. polycystum. Algae $S$. illicifolium in $\mathrm{KOH}$ 4M (cellulose) reached 2,707 $\mu g . \mathrm{ml}^{-1}$, then $\mathrm{HCl}$ pH 2 (fucoidan) was 2,477 $\mu$ g. $\mathrm{ml}^{-1}$, then $\mathrm{CaCl}_{2}$ (fucose) was 2,362 $\mu \mathrm{g} \cdot \mathrm{ml}^{-1}$, and in $\mathrm{Na}_{2} \mathrm{CO}_{3}$ (alginates) was 2,134 $\mu \mathrm{g} \cdot \mathrm{ml}^{-1}$. For antiviral, $\mathrm{S}$. polycystum contained the highest antiviral compounds compared to S. illicifolium with $\mathrm{KOH} 4 \mathrm{M}$ (cellulose) solution was reached $67.02 \mu \mathrm{g} . \mathrm{ml}^{-1}$. Then in $\mathrm{Na}_{2} \mathrm{CO}_{3}$ (alginates) which was $33.25 \mu \mathrm{g} \cdot \mathrm{ml}^{-1}$, then $\mathrm{CaCl}_{2}$ (fucose) which was $31.62 \mu \mathrm{g} . \mathrm{ml}^{-1}$, and $\mathrm{HCl} \mathrm{pH} 2$ (fucose) was $30.08 \mu \mathrm{g} \cdot \mathrm{ml}^{-1}$.

The main structural polysaccharide of some algal species as well as terrestrial plants is cellulose. Its linear molecules are formed by the condensation of D-glucose units through $b-(1,4)$ glycosidic bonds. The hydrogen bonding patterns in cellulose are considered as one of the most important factors on its physical and chemical properties including the solubility, crystallinity, and hydroxyl reactivity. Alginates is another compound in marine algae. Alginates without sulfate groups are constituents located in the cell wall and in the matrix of brown 
Table 1. Bioactivity compounds of polysaccharides extract

\begin{tabular}{|c|c|c|c|}
\hline \multirow{2}{*}{ Algae } & \multirow{2}{*}{ Solvents } & \multicolumn{2}{|c|}{ Bioactivity CC $50\left(\mu \mathrm{g} \cdot \mathrm{ml}^{-1}\right)$} \\
\hline & & Cytotoxicity & Antiviral \\
\hline \multirow{4}{*}{ S. polycystum } & $\mathrm{CaCl}_{2}(2 \%)$ & 2005 & 31.63 \\
\hline & $\mathrm{HCl}(\mathrm{pH} 2)$ & 1418 & 30.08 \\
\hline & $\mathrm{Na}_{2} \mathrm{CO}_{3}(3 \%)$ & 1983 & 33.25 \\
\hline & $\mathrm{KOH}(4 \mathrm{M})$ & 1649 & 67.02 \\
\hline \multirow{4}{*}{ S. ilicifolium } & $\mathrm{CaCl}_{2}(2 \%)$ & 2362 & 6.63 \\
\hline & $\mathrm{HCl}(\mathrm{pH} 2)$ & 2477 & 17.29 \\
\hline & $\mathrm{Na}_{2} \mathrm{CO}_{3}(3 \%)$ & 2134 & 19.7 \\
\hline & $\mathrm{KOH}(4 \mathrm{M})$ & 2707 & 17.44 \\
\hline
\end{tabular}

Notes: $\mathrm{CaCl}_{2}(2 \%)$ : Fucoidan; $\mathrm{HCl}\left(\mathrm{pH}\right.$ 2) : Fucoidan; $\mathrm{Na}_{2} \mathrm{CO}_{3}(3 \%)$ : Alginates; $\mathrm{KOH}(4 \mathrm{M})$ : Cellulose/Hemicellulose

seaweeds together with fucans and heteroglycans rich in sulfated L-fucoses (Mišurcová et al., 2015).

Polysaccharides have many pharmacological properties, such as antioxidants, antibacterial, antiviral, immune stimulators, anticoagulants and anti-cancer. Sulfated polysaccharides refer to polysaccharides with sulphate groups on the glycosyl groups, which can be obtained through natural or sulphated structural modifications. It is the most studied class of antiviral polysaccharides. Some natural sulfate polysaccharides such as chondroitin sulfate, heparin, etc., have antibiosis, anti-virus and other biological functions, so that the study of sulfated polysaccharides has received attention (Cheng and Gangliang, 2018). Algal polysaccharides are located mostly in algal cell walls as structural compounds. Their structure and composition were found crucial for their activities on signaling pathway regulating defense of algal cells of unicellular organisms or plant tissue of multicellular algae against the environmental surroundings (Jaulneau et al., 2010; Aquino et al., 2011; Rodrigues et al., 2012).

Furthermore, the activity of cytotoxicity and antiviral could be correlated with the sulfate content as well as nature and chemical composition of the polysaccharides. Recent evidences have also indicated that besides sulfate concentration, a molecular weight of seaweed polysaccharides is also influences their biological behavior (Xu et al., 2017). These factors could explain the lack of antiviral activity found in S. illicifolium. Another statement reported that the biological activity of brown algae is associated with polysaccharide content and also contained polyphenols, especially antioxidant activity. This is because brown algae have polyphenol compounds with many branches of hydroxyl groups in the chain of bonds (Eom et al., 2011; Shin et al. 2014). Furthermore, the polysaccharide compound in algae be effected by the sulfate levels in the main structure of its constituent monosaccharides and also the species of algae (Xu et al. 2017).

Algae lives in an environment filled with pressures such as light, rapid temperature fluctuations, osmotic pressure and desiccation. These factors cause the formation of free radicals and other strong oxidizing agents in algal cells, although algae rarely experience serious photodynamic damage. This fact also implies that algal cells have several protective mechanisms (Holzinger and Karsten, 2013). Thirumurugan and Dhanaraju (2017) said that the polysaccharides in marine algae represent a number of abundant bioactive substances found in marine organisms. Many marine macro- and microorganisms contain carbohydrates of good quality and potential because of their bio-functional properties.

\section{Conclusion}

The results showed that the cytotoxicity of algae S. polycystum was highest containing in $\mathrm{CaCl}_{2} 2 \%$ (fucoidan) and the antiviral was in $\mathrm{KOH} 4 \mathrm{M}$ (cellulose), meanwhile for $S$. ilicifolium showed that the highest cytotoxicity and antiviral activity are highest in $\mathrm{KOH}(4 \mathrm{M})$ (cellulose).

\section{References}

Aquino, R.S., Grativol, C. \& Mourão, P,A,S. 2011. Rising from the sea: correlations between sulfated polysaccharides and salinity in plants. Plos One 6:1-7. doi: 10.1371/journal.pone.00 18862.

Chayavichitsilp, P., Buckwalter, J.V. \& Krakowski. A.C. 2009. Herpes simplex. Pediatr. Rev. 30(4):11929. doi: 10.1542/pir.30-4-119. 
Chen, L. \& Huang, G. 2018. The Antiviral Activity of Polysaccharides and Their Derivatives. Int. J. Bio. Mac. 115:77-82. doi: 10.1016/j.ijbiomac.2018. 04.056 .

Eom, S., Kang, Y., Park, J., Yu, D., Jeong, E., Lee, M. \& Kim, Y. 2011. Enhancement of polyphenol content and antioxidant activity of brown alga Eisenia bicyclis extract by microbial fermentation. Fisch. Aquat. 14: 192-197. doi: 10.5657/FAS.2011.0192.

Gebreyohannes, G. 2014. Human Herpes Simplex Virus Categories, Mode of Transmission, Treatment and Precentive Measures. Int. J. Pharm \& H. Care Res. 02(04):211-226.

Guo, Q., Qiang, S., Wenping, X., Lei, R., Ryo, S., Fumio, E., Zandong, L. 2017. Immunomodulatory and Anti-IBDV Activities of The Polysaccharide AEX from Coccomyxa gloebotrydiformis. Mar. Drugs. 15(2):36. doi: 10.3390/md15020036.

Hardouin, K., Burlot, A.S., Umami, A., Tanniou, A., Stiger-Pouvreau, V., Widowati, I., Bedoux, G. \& Bourgougnon, N. 2013. Bioactive antiviral enzymatic hydrolysates from different invasive French seaweeds. XXIst Int. Seaweed Symp. pp.21-26 doi: 10.1007/s10811-013-0201-6.

Holzinger, A. \& Karsten, U. 2013. Desiccation stress and tolerance in green algae: consequences for ultrastructure, physiological, and molecular mechanisms. Plant. Sci., 4:327. doi: 10.3389/ fpls.2013.00327.

Jaulneau, V., Lafitte, C., Jacquet, C., Fournier, S., Salamagne, S., Briand, X., Esquerré-Tugayé, M.T., Dumas, B. 2010 Ulvan, a sulphated polysaccharide from green algae, activates plant immunity through the jasmonic acid signaling pathway. J. Biomed. Biotechnol., 2010:1-11 doi: 10.1155/2010/525291.

Kelman, D., Posner, E.K., McDermid, K.J., Tabandera, N.K., Wright, P.R., \& Wright, A.D. 2012. Antioxidant activity of Hawaiian marine algae. Mar. Drugs., 10: 403-416. doi: 10.3390/md 10020403.

Laine J., Kuvaja-Köllner V. \& Pietilä E. 2014. Costeffectiveness of population-level physical activity interventions: a systematic review. Am. J. Health Promot. 29(2):71-80. doi: 10.4278/aj hp.131210-LIT-622.

Mišurcová, L., Orsavová, J. \& Vávra Ambrožová, J., 2015 Algal Polysaccharides and Health.
Polysaccharid. Bioactiv. Biotechnolog. doi: 10.1007/978-3-319-03751-6_24-1.

Mustafa, M., EM.Illzam, R.K. Muniandy., A.M. Sharifah., M.K.Nang., B. Ramesh. 2016. Herpes simplex virus infections, Pathophysiology and Management. J. Dental Med. Sci., 15:85-91. doi: 10.9790/0853-150738591.

Peréz, M.J., Elena, F., Herminia, D. 2016. Antimicrobial Action of Compounds of Marine Seaweed. Mar. Drugs., 14(3):52. doi: 10.3390/ md14030052.

Razonable, R.R. 2011. Antiviral Drugs for Viruses Other Human Immunodeficiency Virus. Mayo. Clin. Proc. 86(10):1009-1026. doi: 10. 4065/ mcp.2011.0309.

Rodrigues, J.A.G., Quinderé, A.L.G., de-Queiroz. I.N.L., Coura, C.O. \& Benevides. N.M.B 2012. Comparative study of sulfated polysaccharides from Caulerpa spp. (Chlorophyceae). Biotechnological tool for species identification. Acta Sci. Biol. Sci., 34(4):381-389. doi: 10.4025/actascibiolsci.v34i4.8976.

Rodriguez-Medina, E.M., Bribian, A., Boyd, A., Palomo, V., Pastor, J., Lagares, A., Gil, C., Martinez, A., Williams, A. \& de Caestro, F. 2017. Promoting in vivo remyelination with small molecules: a neuroreparative pharmacological treatment for Multiple Sclerosis. Sci. Rep., 7:43545. doi: 10. 1038/srep43545.

Setyawidati, N., Kaimuddin, A.H., Wati, I.P., Helmi, M., Widowati, I., Rossi, N., Liabot, P.O. \& StigerPouvreau, V. 2018. Percentage cover, biomass, distribution, and potential habitat mapping of natural macroalgae, based on high-resolution satellite data and in situ monitoring, at Libuk Island, Malasoro Bay, Indonesia. J. Appl. Phycol., 30(1):159-171. doi: 10.1007/s10811-017-12 08-1.

Shin, T., Ahn, M., Hyun, J.W., Kim, S.H. \& Moon, C. 2014. Antioxidant marine algae phlorotannins and radioprotection: A review of experimental evidence. Acta Histochem. 116:669-674. doi: 10.1016/j.acthis.2014.03.008.

Thirumurugan, G., M.D. Dhanaraju. 2017. Marine Polysaccharides as Multifunctional Pharmaceutical Excipients. Biological Activities and Application of Marine Polysaccharides. p. 129. doi: 10.5772/66191.

Vadlapudi, A.D., Vadlapatla, R.K. \& Mitra, A.K. 2013. Update on emerging antivirals for the 
management of herpes simplex virus infections: a patenting perspective. Recent Pat. Antiinfect. Drug Discov., 8(1).55-67. doi: 10.2174/15 74891X11308010011.
Xu, Shu-Ying., Xuesong, H. \& Kit-Leong, C. 2017. Recent Advances in Marine Algae Polysaccharides: Isolation, Structure and Activities. Mar. Drugs., 15(12):388. doi: 10.339 0/md15120388. 